\title{
Manajemen dan Organisasi Informasi : Studi di Fakultas Teknologi Informasi Universitas Kristen Satya Wacana Salatiga
}

\author{
Albertoes Pramoekti Narendra \\ Program Studi S1 Ilmu Perpustakaan \\ Fakultas Teknologi Informasi UKSW Salatiga Jawa Tengah \\ Email: alberto.pramukti@uksw.edu ; beetpram@gmail.com
}

\begin{abstract}
This study aims to find out about the process of activities from the beginning to the end about the management and organization of information held at the Information Technology Faculty of Satya Wacana Christian University in Salatiga. This study This study used a qualitative approach using the case study method. One interesting thing to do is that in the management activities of stored information various kinds of documents result from various activities of the academic community. Documents and information held by the Information Technology Faculty are divided into 2 groups. The first group is an archival document and the second group is a library document. This research focuses on managing library documents. In implementing this management and information organization activities, the SWCU Information Technology Faculty formed a task force under the name of the Center for Documentation and Scientific Information. The main task of the task unit is to plan, carry out and make reports on the implementation of tasks. The results of this study that the organization and retrieval of information and documents using the information system diagramming framework introduced by Doyle. Some of the problems that were encountered were that the space available for this activity was incomplete and was still waiting for the purchase or procurement of various equipment to support the creation of better and more adequate information organizing activities.
\end{abstract}

Key Words: Information Organization; Documentation; Management

\begin{abstract}
Abstrak
Penelitian ini bertujuan untuk mengetahui tentang proses kegiatan dari awal hingga akhir tentang manajemen dan pengorganisasian informasi yang dimiliki di Fakultas Teknologi Informasi Universitas Kristen Satya Wacana Salatiga. Penelitian ini Penelitian ini menggunakan pendekatan kualitatif dengan menggunakan metode studi kasus. Salah satu hal yang menarik dilakukan bahwa dalam kegiatan tata kelola informasi tersimpan berbagai
\end{abstract}


macam dokumen hasil dari berbagai aktivitas sivitas akademika. Dokumen dan informasi yang dimiliki oleh Fakultas Teknologi Informasi terbagi dalam 2 kelompok. Kelompok pertama adalah dokumen kearsipan dan kelompok kedua adalah dokumen perpustakaan. Penelitian ini memfokuskan pada pengelolaan dokumen perpustakaan. Dalam pelaksanaan kegiatan manajemen dan organisasi informasi ini Fakultas Teknologi Informasi UKSW membentuk satuan tugas dengan nama Pusat Dokumentasi dan Informasi Ilmiah. Tugas pokok satuan tugas adalah merencanakan, melaksanakan dan membuat laporan pelaksanaan tugas. Hasil dari penelitian ini bahwa pengorganisasian dan temu kembali informasi dan dokumen menggunakan kerangka pemikiran diagram sistem informasi yang diperkenalkan oleh Doyle. Beberapa permasalahan yang ditemui bahwa ruangan yang tersedia untuk kegiatan ini belum lengkap dan saat ini masih menunggu pembelian atau pengadaan berbagai perlengkapan untuk mendukung terciptanya aktivitas pengorganisasian informasi yang semakin baik dan memadai.

Kata Kunci : Organisasi Informasi; Dokumentasi; Manajemen

\section{A. PENDAHULUAN}

Setiap organisasi yang tumbuh dan berkembang menghasilkan informasi dan data. Data tersebut bersumber dari aktifitas rutin yang dilakukan oleh segenap staf yang terlibat di dalam organisasi. Informasi yang dimiliki oleh masing masing organisasi bersifat unik dan tidak sama dengan organisasi yang lain. Demikian juga dengan kebutuhan informasi serta penyebaran hasil pengolahan data juga berbeda antar organisasi. Hal itu terkait dengan kehidupan organisasi yang terus tumbuh dan berkembang serta tujuan yang ingin dicapai.

Ada berbagai macam tipe organisasi dan salah satu organisasi yang juga mengelola informasi dalam jumlah yang cukup besar adalah perguruan tinggi. Informasi tersebut perlu diorganisir agar terkumpul dan dapat berguna bagi seluruh unsur dalam organisasi. Robert J. Glushko, mengenai organisasi informasi sebagai berikut "When organizing information involves creating and arranging tangible artifacts-carving in stone, imprinting in clay, applying ink to paper by hand or with a printing press-and then putting the artifacts into boxes, bins, cabinets, or shelves, the affordances (Gibson, 1977) and the implications for information retrieval and use are immediately evident." (Glushko, 2013)

Sebuah institusi perguruan tinggi dengan tugas utama tri dharma perguruan tinggi yang meliputi pengajaran, penelitian dan pengabdian pada 
masyarakat. Dalam bidang pengajaran menghasilkan berbagai bahan ajar yang bersumber dari berbagai literature baik tercetak maupun digital. Dalam bidang penelitian menghasilkan berbagai karya ilmiah dan hasil penelitian. Dalam bidang pengabdian masyarakat akan menghasilkan berbagai laporan hasil pengabdian pada masyarakat yang memiliki dampak bagi pemberdayaan masyarakat yang didampingi. Berbagai data tersebut terkumpul dan dikelola oleh institusi perguruan tinggi sebagai hasil dari proses bisnis organisasi sehingga dalam kurun waktu tertentu akan terkumpul sejumlah besar data, informasi dan dokumen yang sangat perlu untuk dikelola lebih lanjut dalam rangka menjamin kepastian bukti-bukti kegiatan organisasi dan membutuhkan tata kelola yang baik sehingga dapat dipergunakan untuk proses pengambilan keputusan organisasi dimasa mendatang.

Hal tersebut juga senada dengan pendapat dari Margaret Rouse yang menulis bahwa Big data management is the organization, administration and governance of large volumes of both structured and unstructured data. The goal of big data management is to ensure a high level of data quality and accessibility for business intelligence and big data analytics applications. Corporations, government agencies and other organizations employ big data management strategies to help them contend with fast-growing pools of data, typically involving many terabytes or even petabytesof information saved in a variety of file formats. Effective big data management helps companies locate valuable information in large sets of unstructured data and semi-structured data from a variety of sources, including call detail records, system logs and social media sites. (Rouse, 2016)

Fakultas Teknologi Informasi UKSW sebagai salah satu organisasi pendidikan tinggi juga memiliki berbagai macam data yang tercipta sebagai hasil dari proses kegiatan organisasinya. Data tersebut masih memerlukan penanganan lebih baik mengingat belum ada sebuah pengelolaan yang bertujuan untuk pengorganisasian data dan informasi yang lebih baik dan kemudahan temu kembalinya. Data yang dimiliki oleh Fakultas Teknologi Informasi memiliki dua kategori yaitu (1) data kearsipan dan (2) data kepustakaan. Dua jenis data ini memiliki sifat yang berbeda dimana data kearsipan tidak semua orang memiliki hak akses terhadap kandungan informasinya. Sedangkan data kepustakaan memberikan kemudahan pada semua orang untuk mengakses informasi yang terkandung di dalam pustaka tersebut. Penelitian ini akan mengamati Manajemen dan Organisasi Informasi dokumen Fakultas Teknologi Informasi terkait dengan data pustaka yang dimiliki. Data pustaka ini berupa berbagai artikel yang termuat di dalam 
jurnal, prosiding, serta koleksi teks book dan koleksi karya ilmiah digital lain yang ada dalam lingkup Fakultas Teknologi Informasi yang dihasilkan oleh para dosen dan mahasiswa FTI dan saat ini berbagai data yang sangat besar tersebut masih belum dikelola dengan lebih baik.

Dari latar belakang tersebut maka penelitian ini akan menggali informasi dan juga kegiatan Organisasi Informasi yang secara spesifik dan memiliki kekhususan dibandingkan dengan instansi lain di lingkungan Fakultas Teknologi Informasi dalam kerangka pengembangan pusat dokumentasi dan informasi ilmiah.

\section{Rumusan Masalah}

Dari latar belakang permasalahan yang dihadapi oleh Fakultas Teknologi Informasi UKSW maka rumusan masalah yang diambil adalah Bagaimanakah upaya yang dilakukan oleh pimpinan Fakultas Teknologi Informasi dalam mengelola sejumlah besar data, informasi dan dokumen ada di lingkungan FTI dengan dukungan teknologi informasi sehingga memudahkan dalam pengorganisasian informasi dan dokumen dimasa yang akan datang.

\section{Landasan Teoritik}

Berdasarkan hasil wawancara dari informan yang tergabung dalam satgas Pusat dokumentasi, kerangka kerja dalam pengembangan Pusat Dokumentasi dan Informasi Ilmiah, mengacu pada kerangka pemikiran yang diperkenalkan oleh Lauren B. Doyle dalam artikelnya yang dimuat sebuah jurnal The Library Quarterly volume 47 no.3 tahun 1977 https://www.journals.uchicago.edu/doi/abs/10.1086/620709. Lauren B. Doyle. Information Retrieval and Processing.

Kerangka kerja tersebut merupakan serangkaian proses kegiatan manajemen pengelolaan informasi dan dokumen yang sampai saat ini masih relevan digunakan dilingkungan lembaga perpustakaan, dokumentasi dan informasi. 


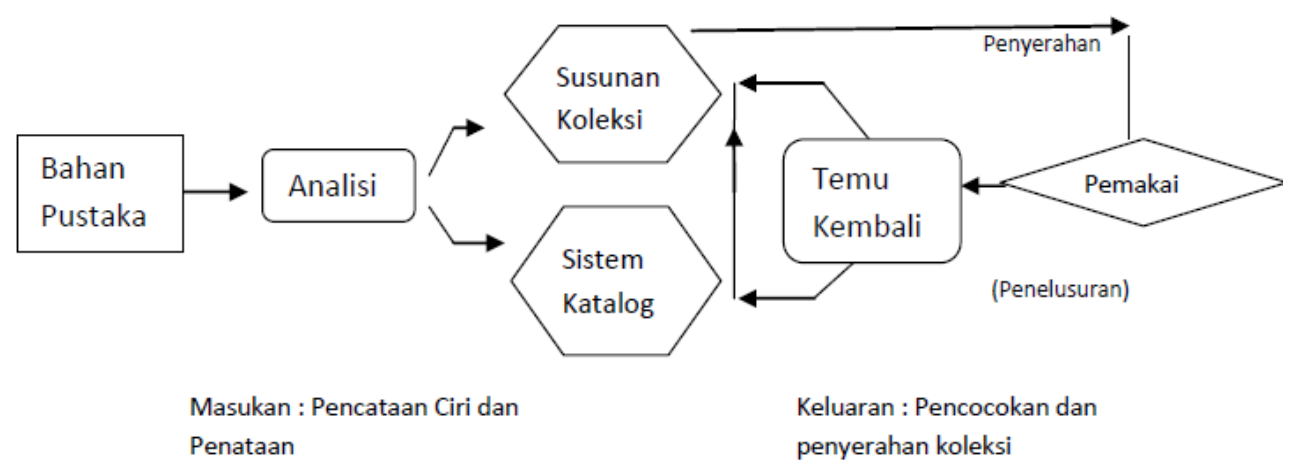

Gambar 1

Diagram Information Retrieval and Processing Lauren B. Doyle

Dalam kerangka kerja tersebut mencakup seluruh proses kegiatan yang dimulai dari keadaan awal dokumen hingga proses penyerahan informasi dan dokumen yang dibutuhkan oleh pihak pengguna organisasi. Berdasarkan hasil wawancara dari informan, kerangka kerja yang digunakan ini juga dilengkapi dengan SOP (Standard Operating Procedure) sebagai pedoman dalam pelaksanaan masing masing kegiatan yang dilakukan.

\section{Metode}

Penelitian ini menggunakan pendekatan kualitatif dengan menggunakan metode studi kasus. Menurut Sugiyono penelitian kualitatif adalah penelitian yang berlandaskan pada filsafat postpositivisme. Digunakan untuk meneliti pada kondisi obyek yang alamiah. Peneliti berperan sebagai instrumen kunci. Teknik pengumpulan data dilakukan secara triangulasi (gabungan), analisi data bersifat induktif/kualitatif, dan hasil penelitian kualitatif lebih menekankan makna daripada generalisasi (Sugiyono, 2009).

Kartono dan Gulo mengemukakan bahwa Studi Kasus atau Case Study merupakan suatu metode pengumpulan data yang bersifat integrative dan comprehensive. Integrative artinya menggunakan berbagai teknik pendekatan dan bersifat comprehensive yaitu data yang dikumpulkan meliputi keseluruhan. Dengan cara pemeriksaan mendalam terhadap suatu keadaan atau kejadian yang disebut sebagai kasus dengan menggunakan caracara yang sistematis dalam melakukan pengamatan, pengumpulan data, analisis informasi, dan pelaporan hasilnya (Kartono, 2011).

Karena studi kasus yang mana menekankan pada analisis detail yang bersifat kontektual rinci sejumlah peristiwa atau kondisi. Maka dari itu, studi 
kasus menjadi aspek yang penting untuk dicantumkan di dalam penelitian ilmiah. Terdapat tiga tipe dari studi kasus, yaitu eksploratoris, deskriptif, dan eksplanatoris. Tipe studi kasus eksplanatoris memiliki karakteristik, yaitu apabila studi kasus yang ada hanya mempertanyakan aspek "apa" dari $4 \mathrm{~W}$ $1 \mathrm{H}$, dan studi kasus yang sifatnya eksploratoris bertujuan untuk mencari jawaban pasti dan bukan mencari alasan. Sedangkan, tipe studi kasus deskriptif khusus untuk jenis pertanyaan "siapa" dan "di mana", yang mana di dalam pencarian studi kasus tipe deskriptif ini diperlukan penelitian langsung atau survei dengan bantuan catatan arsip. Lalu, yang terakhir adalah tipe studi kasus eksplanatoris yang mana menjurus pada pertanyaan "mengapa" dan "bagaimana", yang mana pertanyaan tersebut merupakan bentuk pertanyaan ilmiah yang problematis dan membutuhkan penjabaran atau eksplanasi untuk mencari jawaban dari pemetaan hubungan antar variabel hingga mengarah pada suatu konsep (Yin,2003) Dalam penelitian ini peneliti menggunakan pendekatan eksplanatoris untuk bisa memberikan penjelasan terkait dengan permasalahan dan cara penanganan yang dilakukan oleh Fakultas TI terkait dengan manajemen sekumpulan besar data yang menjadi bagian dari proses bisnis Fakultas Teknologi Informasi UKSW. Sehingga fokus penelitian ini adalah "Bagaimana upaya yang dilakukan dalam penanganan atau manajemen data besar yang dimiliki FTI UKSW. (Yin, 2003)

Subyek dalam penelitian ini adalah satu orang dosen yang menjadi satuan tugas kegiatan penanganan manajemen data dan dokumen yang diwujudkan dalam sebuah unit pusat dokumentasi dan dibantu dengan empat orang mahasiswa. Unit ini disebut sebagai Pusat Dokumentasi dan Informasi Ilmiah. Seperti yang dinyatakan oleh Arikunto bahwa subyek penelitian adalah sumber data yang dimintai informasinya sesuai dengan masalah penelitian.(Suharsimi, 2010). Subyek penelitian ini dipilih berlandaskan teknik purposive sampling. Sugiyono mengatakan bahwa purposive sampling adalah teknik pengambilan sampel sumber data dengan pertimbangan tertentu. Pertimbangan tertentu ini dapat diartikan bahwa sumber tersebut merupakan tokoh utama atau orang yang memiliki peran sentral sehingga mengetahui tentang penelitian yang akan dilaksanakan. (Sugiyono, 2002)

Sehingga dengan demikian memudahkan peneliti untuk melakukan pendalaman dari obyek atau situasi yang hendak diteliti. Instrumen penelitian dalam penelitian kualitatif adalah peneliti tersebut. Moleong menulis bahwa kedudukan peneliti dalam penelitian kualitatif cukup rumit. Tugasnya sekaligus sebagai perencana, pelaksana pengumpulan data, analisis, 
penafsiran, dan menjadi pelapor hasil penelitiannya tersebut. (Moleong, 2007).

Atas dasar itulah maka peneliti terlibat di dalam proses penelitian. Kegiatan wawancara dan observasi dilakukan oleh peneliti untuk menggali data yang berguna dalam menyusun laporan terkait dengan tema penelitian. Adapun metode pengumpulan data dilakukan dengan melakukan observasi pada kegiatan yang dilakukan oleh satuan tugas pusat dokumentasi dan wawancara terhadap subyek penelitian atau informan. Informasi yang telah terkumpul dari kegiatan observasi dan wawancara pada langkah selanjutnya perlu dilakukan analisis. Teknik analisis data merupakan proses sistematis pencarian dan pengaturan transkripsi wawancara, catatan lapangan dan materi materi lain yang telah dikumpulkan untuk meningkatkan pemahaman mengenai materi materi tersebut dan untuk menyajikan hasil yang sudah ditemukan kepada orang lain.(Emzir, 2010) Teknik analisis domain digunakan dalam penelitian ini. Teknik analisis domain menurut Bungin digunakan untuk menganalisis gambaran obyek penelitian secara umum atau diangkat ke permukaan namun relatif utuh tentang obyek penelitian tersebut. (Burhan, 2005)

\section{B. HASIL DAN PEMBAHASAN}

\section{Landasan Operasional}

Pelaksanaan kegiatan manajemen dan organisasi informasi di lingkungan Fakultas Teknologi Informasi dituangkan dalam surat tugas Rektor UKSW. Surat tugas ini terbit dengan dilandasi oleh keputusan rapat di lingkungan fakultas yang menyepakati dibentuknya satuan tugas yang menangani pengelolaan sejumlah besar data, informasi dan dokumen yang terus bertambah di fakultas Teknologi Informasi. Personalia satuan tugas terdiri atas dosen, staf administrasi dan mahasiswa.

\section{Data dan Dokumen Fakultas}

Fakultas Teknologi Informasi UKSW memiliki data dan dokumen yang sangat beragam. Dari beragamnya data dan dokumen yang ada maka satuan tugas mengelompokkan dalam dua kelompok yaitu:

1. Data dan dokumen yang bisa diakses oleh sivitas akademika secara terbuka

2. Data dan dokumen terbatas untuk diakses sivitas akademika tertentu Data yang tercatat catat jumlah dosen sekitar 75 orang dan jumlah mahasiswa lebih dari 3000 orang. Dari data tersebut menciptakan luaran 
90 | Albertoes Pramoekti Narendra: Manajemen dan Organisasi ...

berupa hasil karya berupa data dan dokumen baik tekstual, visual maupun multi media.

Di dalam penelitian ini peneliti akan memfokuskan pada manajemen data dan dokumen dengan kategori data yang bisa diakses secar terbuka oleh sivitas akademika. Data tekstual : berupa (1) karya ilmiah yang dipublikasikan dalam jurnal dan prosiding (2) tugas akhir tertulis (3) laporan kerja praktek (4) modul modul pembelajaran (4) artikel artikel yang tidak dipublikasikan dalam jurnal. Data visual dapat berupa (1) karya fotografi (2) lukisan (3) poster. Data multimedia berupa (1) rekaman video tugas dan promosi (2) hasil karya cipta mahasiswa dan dosen yang dituangkan dalam bentuk multi media.

Tabel 1. Dokumen dalam Lingkungan Fakultas Teknologi Informasi

\begin{tabular}{|l|l|l|l|}
\hline No & \multicolumn{1}{|c|}{ Jenis Koleksi } & Type Koleksi & \multicolumn{1}{|c|}{ Jumlah } \\
\hline 1 & Jurnal dan Prosiding & Text & + +- 1000 eksemplar \\
\hline 2 & $\begin{array}{l}\text { Karya fotografi, lukisan } \\
\text { dan poster }\end{array}$ & Visual & + +- 400 karya \\
\hline 3 & Laporan Kerja Praktek & $\begin{array}{l}\text { Text dan } \\
\text { digital }\end{array}$ & $+/-2000$ judul \\
\hline 4 & Rekaman video & Multi Media & $+/-80$ judul \\
\hline 5 & Perancangan system & Text & $+/-300$ judul \\
\hline & & & \\
\hline
\end{tabular}

Dari tabel 1 tersebut nampak bahwa banyak dokumen tercipta dan perlu dikelola secara lebih baik sehingga memberikan nilai tambah fakultas serta memberikan kemudahan akses bagi pihak pihak yang memerlukan. Seiring dengan perjalanan waktu dimasa mendatang, pertumbuhan data, informasi dan dokumen akan semakin bertambah banyak.

Pencatatan dokumen saat ini mulai dilakukan. Pencatatan tersebut berguna untuk mengenal lebih awal mengenai jenis dokumen dan pemberian identitas sehingga dokumen yang sejenis akan mengelompok.

\section{Analisis Data dan Dokumen}

Langkah yang selanjutnya adalah proses analisis. Informasi yang diperoleh dari informan mengatakan bahwa proses analisis adalah kegiatan mengenali dokumen secara lebih mendalam baik dari segi fisiknya maupun kandungan informasi yang tersaji di dalamnya. Proses kegiatan analisis ini 
meliputi analisa deskripsi dan analisa subyek. Analisa deskripsi merupakan tugas yang dilakukan oleh satuan tugas untuk mengenal data dan dokumen dari segi fisiknya. Analisis ini menggunakan pedoman tertentu. Pedoman yang digunakan mengacu pada standar internasional yaitu International Standar Bibliographic Description (ISBD General). Standar ini dituangkan dalam bentuk peraturan tertulis pendeskripsian dokumen yang dikenal dengan nama Anglo American Cataloguing Rules (AACR) dimana dalam langkah ini anggota satuan tugas melaksanakan kegitan pendeskripsian dokumen secara fisik atau deskripsi bibliografis. Beberapa data penting yang diperoleh dari kegiatan deskripsi bibliografis ini antara lain terkait dengan (1) judul dan penanggungjawab sebuah karya (2) edisi (3) data khusus jika dokumen tersebut bersifat elektronis (4) data tempat penerbitan, nama penerbitan dan tahun penerbitan (5) data fisik terkait dengan jumlah halaman dan keterangan gambar, keterangan ukuran dokumen. (6) keterangan atau catatan dokumen tersebut misalnya mengenai abstrak, ketersediaan halaman indeks, dan daftar referensi (7) nomor standar internasional. Informasi tersebut penting untuk diidentifikasi sehingga memudahkan temu kembali ketika dibutuhkan.

Kegiatan yang berikutnya adalah analisis terkait dengan topik atau tema yang terkandung dalam sebuah dokumen. Proses analisis ini membutuhkan wawasan pengetahuan yang memadai dari anggota satuan tugas. Di dalam proses ini anggota satuan tugas menetapkan klasifikasi keilmuan dan subyek dalam sebuah dokumen. Proses analisis klasifikasi ini juga menggunakan pedoman atau acuan yaitu Dewey Decimal Classification (DDC). Kegiatan klasifikasi sangat penting dalam pengelolaan sebuah dokumen. Klasifikasi yang digunakan dalam implementasi Pusat Dokumentasi ini mengacu pada kegiatan klasifikasi untuk dokumen di lembaga perpustakaan. Kegiatan klasifikasi ini memberikan manfaat bahwa dokumen yang mencakup pustaka cetak, tulisan tangan, majalah, foto, poster, video, film dan lain lain akan disusun dengan susunan yang paling memberikan manfaat bagi perpustakaan maupun lembaga dokumentasi. Sulistyo Basuki menjelaskan bahwa Tujuan lain dari pengklasifikasian dokumen antara lain : (1). Menghasilkan urutan yang bermanfaat, (2) penempatan dokumen yang tepat, (3) penyusunan secara mekanis, (4) memudahkan bila ada penambahan materi baru yang masuk (5) terjadinya klasifikasi informasi dan dokumen (6) menuntut bagi pengguna dalam menemukan sebuah dokumen di dalam jajaran koleksi. (Basuki, 1991) 
Kegiatan yang dilakukan selanjutnya adalah penetapan subyek dokumen. Kegiatan menetapkan subyek sebuah dokumen, menggunakan acuan tajuk subyek Perpustakaan Nasional RI. Sulisyo Basuki menulis bahwa tajuk subyek merupakan kata atau kelompok kata yang menunjukkan subjek sebuah buku atau materi perpustakaan lainnya pada katalog atau bibliografi yang tersusun menurut abjad. (Basuki, 1991)

Adapun tujuan pengkatalogan subjek menurut Perpustakaan Nasioanl RI ( 2011) adalah :

1. Tujuan pengatalogan subjek adalah mendaftarkan subjek tertentu di bawah kata, frasa atau istilah yang seragam untuk koleksi perpustakaan atau lembaga informasi lainnya. Teknis pengetikan tajuk subjek dapat menggunakan cetak tebal atau huruf kapital untuk membedakan dari tajuk yang lain. Selain itu ada juga tujuan lain :

2. menyediakan akses subjek terhadap semua materi perpustakaan melalui prinsip penataan subyek yang sesuai, misalnya berdasarkan proses, aplikasi, masalah dsb.

3. menyatukan rujukan pada materi perpustakaan yang secara substansi memiliki subjek yang sama dengan tidak memandang perbedaan terminologi; perbedaan tersebut muncul karena perbedaan nasional, perbedaan antara kelompok spesialis subjek dan atau karena perubahan sifat konsep dalam disiplin itu sendiri. Perbedaan nasional misalnya istilah railway (Inggeris) dan railroad (AS); tissue diantara biolog dengan pertekstilan

4. menunjukkan afiliasi di antara bidang-bidang subjek. Afiliasi tersebut tergantung pada kesamaan masalah atau metode atau titik pandang masalah yang dikaji atau tergantung pada penggunaan atau aplikasi pengetahuan

5. memberikan titik masuk pada bidang subjek pada setiap tingkat analisis, mulai dari yang paling umum sampai dengan yang paling spesifik

6. menyediakan titik masuk melalui setiap kosakata yang lain bagi setiap kelompok pemakai, baik pemakai khusus maupun awam

7. memberikan deskripsi formal isi subjek dari setiap unit bibliografis dalam istilah yang paling tepat atau paling spesifik; deskripsi tersebut 
dapat berbentuk kata tunggal atau frase atau dalam bentuk nomor kelas atau symbol

8. memberikan sarana bagi pemakai untuk memilih dari semua butiran dalam setiap kategori, menurut kriteria tertentu seperti yang paling mutakhir, paling lengkap,paling sederhana dsb

Subyek digunakan untuk memudahkan sivitas akademika menemukan kembali dokumen yang sudah tersimpan di dalam susunan koleksi dokumen.

Berdasarkan penuturan informan, data dan dokumen yang ada di Fakultas Teknologi Informasi lebih relevan dianalisis dengan menggunakan acuan standar untuk dokumen perpustakaan.

\section{Otomasi Dokumen}

Dalam rangka memudahkan dalam pencatatan, pengolahan, pengindeksan dan temu kembali maka perlu dikembangkan sebuah sistem informasi agar koleksi dan dokumen milik Fakultas dapat tergorganisir dengan baik dan mudah ditemukan kembali. Pengembangan sebuah sistem informasi juga akan membantu bagi pengelola Pusat Dokumentasi dan Informasi Ilmiah untuk mengembangkan layanan berbasis teknologi informasi. Implementasi teknologi informasi dalam pengelolaan dokumen dilakukan dengan menggunakan SLIMS. Pemanfaatan software SLIMS ini telah dipertimbangkan sebelumnya. SLIMS dipilih sebagai sarana untuk meningkatkan kinerja Pusat Dokumentasi FTI karena di dalam aplikasi open source (https://slims.web.id/web/).

Dari sistem open source ini penulis dapat memberikan pendapat bahwa aplikasi ini memiliki beberapa kelebihan antara lain : (1) tersedia secara open source sehingga setiap orang dalam mengunduh dan mempelajari, baik untuk pemula maupun dikembangkan lebih lanjut (2) memiliki banyak kelompok yang saling berdiskusi; pada saat salah satu pengguna mengalami kesulitan (3) mampu mengelola metadata baik dokumen digital maupun dokumen tercetak (4) dapat saling terhubung antar pangkalan data dengan protocol Z39,50 (4) Berbasis web sehingga dapat diakses secara terbuka. Dan masih banyak kemampuan lain yang dimiliki oleh sistem ini. Di dalam pangkalan data digital selain informasi berupa metadata dari dokumen, juga dilengkapi dengan foto dari cover dokumen serta daftar isi dokumen. Hal ini merupakan langkah yang baik karena pengguna informasi akan langsung mengetahui mengenai topik pembahasan sebuah dokumen dengan membaca daftar isinya. 


\section{Diskusi} sebagai berikut :

Dari penelitian ini maka dapat penulis diskusikan beberapa hal

1. Dalam pengelolaan informasi dan dokumentasi dikenal bahwa ada dokumen yang dapat diakses secara terbuka oleh semua orang tersimpan antara lain di Perpustakaan, pusat dokumentasi, pusat referral. Sedangkan dokumen yang hanya bisa diakses secara terbatas untuk keperluan organisasi disimpan di ruang arsip maupun nama lain yang ditetapkan masing-masing lembaga.

2. Fakultas Teknologi Informasi UKSW sebagai institusi pendidikan tinggi menghasilkan berbagai dokumen baik yang sifatnya terbuka untuk publik maupun dokumen yang hanya berguna untuk proses bisnis lembaga tersebut. Berbagai dokumen tersebut memerlukan kegiatan identifikasi dan analisis agar dapat berguna. Berkaitan dengan hal tesebut maka dibentuklah sebuah satgas Pusat Dokumentasi Fakultas agar mampu menangani berbagai hasil kegiatan pembelajaran.

3. Pengelolaan dokumen tidak terlepas dari kegiatan analisis. Dokumen yang ada perlu ditangani dengan sistem yang memastikan bahwa dokumen tersebut dikenali dan diberikan atribut sehingga ketika disimpan, dapat ditemukan kembali dengan lebih cepat. Bandingkan apabila dokumen yang jumlahnya sangat banyak tersebut tidak dilakukan pengelolaan, tentu akan menimbulkan persoalan dalam penyimpanan dan temu kembali. Kegiatan analisis yang dilakukan antara lain analisis deskripsi. Kegiatan ini menghasilkan informasi mengenai keadaan fisik sebuah dokumen atau yang dikenal juga dengan metadata atau deskripsi bibliografis. Kegiatan analisis berikutnya adalah klasifikasi dan analisa subyek. Tugas ini merupakan tugas yang bertujuan untuk mengenal kandungan informasi dari sebuah dokumen. Tugas ini merupakan tugas professional karena membutuhkan wawasan pengetahuan yang luas dan mampu melakukan identifikasi subyek dokumen. Demikian juga dilakukan dalam pusat dokumentasi FTI UKSW. Hasil dari kegiatan analisis subyek adalah pernyataan verbal sebuah subyek dokumen. Pada umumnya kegiatan analisis subyek dipertajam dengan buku 
acuan untuk menetapkan subyek dokumen. Implementasi di Pusat Dokumentasi FTI analisis subyek menggunakan alat bantu DDC.

4. Pusat Dokumentasi Fakultas Teknologi Informasi menempatkan dokumen berupa buku dan karya ilmiah lain yang mudah dijangkau oleh pengguna. Sedangkan dokumen yang hanya hanya bermanfaat bagi proses bisnis lembaga disimpan di tempat yang hanya bisa diakses untuk kebutuhan staf di dalam lembaga. Proses identifikasi ini membutuhkan pemahaman mengenai dokumen dan cara pengelolaannya.

5. Pusat Dokumentasi Fakultas mengelola informasi dan dokumen agar dapat ditemu kembali dengan cepat dan mudah. Dokumen yang masih memiliki nilai guna akan terus disimpan. Nilai guna antara lain untuk sejarah, penelitian, pengetahuan dan bukti pertanggungjawaban organisasi. Ketersediaan dokumen baik secara fisik maupun metadata sangat berguna bagi perkembangan organisasi dan pendukung proses pengambilan keputusan. Demikian pula praktik pengelolaan dokumen di Fakultas Teknologi Informasi UKSW didasarkan pada nilai guna dari berbagai dokumen. Dokumen yang bernilai guna sebagai bukti pertanggungjawaban maupun juga bukti fisik sebuah aktivitas yang pernah dilakukan, terlebih juga sebagai bukti dalam proses kegiatan Akreditasi dan Re-Akreditasi.

6. Pusat Dokumentasi Fakultas Teknologi Informasi mengembangkan perangkat lunak berbasis open source SLIMS. Perangkat lunak ini didesain untuk mampu menangani pengelolaan dokumen perpustakaan secara terotomasi.

\section{KESIMPULAN}

Dari hasil penelitian ini penulis dapat menyampaikan kesimpulan bahwa proses pembelajaran di lingkungan Fakultas Teknologi Informasi menghasilkan berbagai dokumen baik dalam media cetak maupun digital. Dokumen tersebut mulai dikelola dengan pendekatan pengorganisasian informasi dokumen perpustakaan. Prosedur kegiatan pengelolaan dokumen yang dimiliki oleh Pusat Dokumentasi FTI UKSW dimulai dengan langkah identifikasi dan analisis. Analisis ini bertujuan untuk mengenali secara lebih mendalam tentang keadaan fisik dan subyek atau topik yang terkandung dalam sebuah dokumen. Kegiatan analisis telah menggunakan aturan yang berlaku yaitu menggunakan aturan pendeskripsian AACR dan penetapan subyek dari Perpustakaan Nasional RI. Di dalam kegiatan pengembangan 
96 | Albertoes Pramoekti Narendra: Manajemen dan Organisasi ...

layanan informasi menyesuaikan dengan perkembangan teknologi informasi. Pusat Dokumentasi FTI UKSW menggunakan perangkat lunak open source SLIMS dalam kegiatan pendeskripsian serta akses informasi digital bagi pengguna. Sedangkan pengembangan kegiatan Digital Asset Management masih dalam kerangka penyusunan konsep pelaksanaan agar asset digital tetap lestari tanpa harus mengganti perangkat lunak secara periodik.

\section{Saran}

1. Pusat Dokumentasi FTI UKSW yang sedang dalam tahap dikembangkan perlu memiliki roadmap pengembangan sehingga pada waktu tertentu terwujud sebuah Pusat Dokumentasi yang handal.

2. Pusat Dokumentasi perlu memiliki kerangka pemikiran Digital Asset Management mengingat dokumen yang tercipta di masa mendatang lebih banyak berbentuk dokumen digital.

\section{DAFTAR RUJUKAN}

Basuki, S. (1991). Pengantar Ilmu Perpustakaan. Jakarta: Gramedia.

Burhan, B. (2005). Analisis Data Penelitian Kualitatif . Jakarta: Raja Grafindo Persada.

Doyle, L. B. (n.d.). Retrieved 1977, from https://www.journals.uchicago.edu/doi/abs/10.1086/620709

Emzir. (2010). Metodologi Penelitian Pendidikan. Jakarta: Rajawali Pers.

Glushko, R. J. (2013). The discipline of organizing. Retrieved from https://onlinelibrary.wiley.com/doi/full/10.1002/bult.2013.172040010 8

Moleong, L. (2007). Metodologi Penelitian Kualitatif. Bandung: PT. Remaja Rosdakarya.

Rouse, M. (2016). Big data management. Retrieved from https://searchdatamanagement.techtarget.com/definition/big-datamanagement

Sugiyono. (2002). Metode Penelitian Administrasi . Bandung: Alfabeta.

Sugiyono. (2009). Memahami Penelitian Kualitatif. Bandung: CV. Alfabeta.

Suharsimi, A. (2010). Prosedur Penelitian Suatu Pendekatan Praktek. Jakarta: PT. Rineka Cipta.

Yin, R. K. (2003). Introduction dalam Case Study Research . London: Sage. 